\title{
PENGATURAN HAK PENDIDIKAN DISABILITAS (sebagai persiapan penerapan teknologi berkemanusiaan)
}

\author{
Wiwik Afifah, Syofyan Hadi \\ Fakultas Hukum Universitas 17 Agustus 1945 Surabaya \\ Email :wiwikafifah@untag-sby.ac.-id, syofyan@untag-sby.ac.id
}

\begin{abstract}
ABSTRAK
Penyandang disabilitas di Indonesia, sebagian besar hidup dalam kondisi rentan dan pengurangan atau penghilangan hak penyandang disabilitas. Untuk mewujudkan kesamaan hak dan kesempatan bagi penyandang disabilitas menuju kehidupan yang sejahtera, mandiri, dan tanpa diskriminasi diperlukan peraturan perundang-undangan yang dapat menjamin pelaksanaannya.Hak untuk memperoleh pendidikan merupakan hak asasi manusia yang dijamin dalam Pasal 31 ayat (1) Undang-Undang Dasar Negara Republik Indonesia Tahun 1945. Namun dalam prakteknya, anak penyandang disabilitas sangat rentan untuk memperoleh perlakuan diskriminatif dalam memperoleh hak-haknya, khususnya hak atas pendidikan. Hal tersebut disebabkan oleh ketidak-samaan kondisi fisik atau psikis anak penyandang disabilitas. Anak penyandang disabilitas membutuhkan perlindungan dalam memperoleh pendidikan. Pendidikan yang diikuti oleh penyandang disabilitas berguna sebagai bekal dalam kehidupan yang semakin meng-globalberbasis teknologi.

Berdasarkan hal tersebut, penulis memaparkan tentang bagaimana pengaturan mengenai hak pendidikan bagi penyandang disabilitas. Metode penelitian yang dipergunakan adalah penelitian yuridis normative. Kesimpulan dari artikel adalah hak pendidikan penyandang disabilitas telah diatur baik dalam konvensi internasional hak asasi manusia, International Covenant on Economic, Social, and Cultural Rights dan Convention on the Rights of Person with Disabilities dengan Resolusi 61/106, Pasal 28 C ayat (1) dan Pasal 28 E ayat (1) UUD NRI Tahun 1945. Hak atas pendidikan juga telah diatur dalam Undang-Undang Nomor 39 Tahun 1999 tentang Hak Asasi Manusia khususnya Pasal 12. Secara spesifik perlindungan hak penyandang disbilitas termasuk hak pendidikan terdapat dalam Undang-Undang Nomor 8 Tahun 2016 Tentang Penyandang Disabilitas. Selanjutnya, pengaturan di tingkat propinsi yaitu Peraturan Daerah Nomer 3 Tahun 2013 Tentang Perlindungan Dan Pelayanan Penyandang Disabilitas Di Jawa Timur. Begitu pula dengan Peraturan Gubernur Nomor 6 Tahun 2011 Tentang Penyelenggaraan Pendidikan Inklusi.
\end{abstract}

Kata kunci : hak pendidikan, penyandang disabilitas

\section{PENDAHULUAN}

Hukum telah menentukan bahwa anak penyandang disabilitas berhak untuk memperoleh perlakuan khusus untuk memperoleh pendidikan. Hal tersebut telah dijamin oleh Pasal 28H ayat (2) UUD NRI Tahun 1945 yang menentukan "Setiap orang berhak mendapat kemudahan dan perlakuan khusus untuk memperoleh kesempatan dan manfaat yang sama guna mencapai persamaan dan keadilan". Menindaklanjuti ketentuan tersebut, Pasal 5 ayat (2) Undang-Undang Nomor 20 Tahun 2003 tentang Sistem Pendidikan Nasional (selanjutnya disebut UU No. 20 Tahun 2003) menentukan bahwa bahwa "Warga negara yang memiliki kelainan fisik, emosional, mental, intelektual, dan/atau sosial berhak memperoleh pendidikan khusus". Senada dengan hal tersebut, Pasal 51 UndangUndang Nomor 35 Tahun 2014 tentang Perubahan Atas Undang-Undang Nomor 23 Tahun 2002 tentang Perlindungan Anak juga menentukan bahwa "Anak Penyandang Disabilitas diberikan kesempatan dan aksesibilitas untuk memperoleh pendidikan inklusif dan/atau pendidikan khusus". Dengan dasar di atas, maka anak penyandang disabilitas mempunyai hak untuk memperoleh pendidikan inklusi dan/atau pendidikan khusus. 
Untuk memberikan perlindungan maksimum (maximum protection) terhadap penyandang disabilitas termasuk hak atas pendidikan, maka telah ditetapkan Undang-Undang Nomor 8 Tahun 2016 tentang Penyandang Disabilitas (selanjutnya disebut UU No. 8 Tahun 2016). UU tersebut mencabut UU No. 4 Tahun 1997 tentang Penyandang Cacat yang sudah tidak sesuai lagi dengan kebutuhan penyandang disabilitas. Dalam konsideran UU No. 8 Tahun 2016 ditentukan bahwa:

a. bahwa Negara Kesatuan Republik Indonesia menjamin kelangsungan hidup setiap warga negara, termasuk para penyandang disabilitas yang mempunyai kedudukan hukum dan memiliki hak asasi manusia yang sama sebagai Warga Negara Indonesia dan sebagai bagian yang tidak terpisahkan dari warga negara dan masyarakat Indonesia merupakan amanah dan karunia Tuhan Yang Maha Esa, untuk hidup maju dan berkembang secara adil dan bermartabat;

b. bahwa sebagian besar penyandang disabilitas di Indonesia hidup dalam kondisi rentan, terbelakang, dan/atau miskin disebabkan masih adanya pembatasan, hambatan, kesulitan, dan pengurangan atau penghilangan hak penyandang disabilitas;

c. bahwa untuk mewujudkan kesamaan hak dan kesempatan bagi penyandang disabilitas menuju kehidupan yang sejahtera, mandiri, dan tanpa diskriminasi diperlukan peraturan perundang-undangan yang dapat menjamin pelaksanaannya;

Berdasarkan konsideran menimbang di atas terlihat sangat jelas bahwa negara mengakui hakhak penyandang disabilitas sebagai warga negara yang harus dipenuhi tanpa diskriminasi.Salah satu hak penyandang disabilitas yang ditentukan di dalam Pasal 5 ayat (1) UU No. 8 Tahun 2016 adalah "hak pendidikan" (“Undang-Undang Nomor 8 Tahun 2016 tentang Penyandang Disabilitas," n.d.). Dengan demikian, pemerintah dan pemerintah daerah termasuk Pemerintahan Daerah Provinsi Jawa Timur berkewajiban untuk memenuhi hak penyandang disabilitas atas pendidikan. Hal tersebut sesuai dengan Pasal 40 ayat (1) UU No. 8 Tahun 2016 yang menentukan bahwa "Pemerintah dan Pemerintah Daerah wajib menyelenggarakan dan/atau memfasilitasi pendidikan untuk Penyandang Disabilitas di setiap jalur, jenis, dan jenjang pendidikan sesuai dengan kewenangannya". Selain kewajiban tersebut, Pemerintahan Daerah Provinsi Jawa Timur juga mempunyai kewajiban yang lain sebagaimana ditentukan dalam Pasal 40 sampai Pasal 43 UU No. 8 Tahun 2016.

Perkembangan teknologi semakin canggioh dan menuntut manusia untuk beradaptasi. Manusia secara umum banyak yang menghadapi kendala adaptasi teknologi karena kewilayahan, akses pendukung (listrik, internet, dan lainnya), serta pendidikan yang menjadi bekal utama atas penggunaan teknologi. Penyandang disabilitas adalah manusia yang memiliki kemampuan berbeda. Mereka membutuhkan pendidikan dan jaminan atas pendidikan sebagai bekal dalam penggunaan teknologi, dalam kehidupan, pergaulan dan mengembangkan diri.

Dengan urain di atas, maka penyandang disabilitas berhak untuk memperoleh pendidikan dan di sisi yang lain ada kewajiban Pemerintahan Daerah Provinsi Jawa Timur untuk memenuhi. Oleh karena itu, penelitian ini akan mengkaji mengenai sejauh mana hak pendidikan bagi penyandang disabilitas tersebut dipenuhi di Provinsi Jawa Timur. Untuk mengetahui hal tersebut, maka akan dikaji mengenai kebijakan apa yang telah dan akan diambil oleh Pemerintahan Daerah Provinsi Jawa Timur.

\section{RUMUSAN MASALAH}

Berdasarkan latar belakang di atas, maka masalah yang akan dikaji dalam penelitian adalah Bagaimana pengaturan mengenai hak pendidikan bagi penyandang disabilitas?

\section{METODE PENELITIAN}

Penelitian ini adalah penelitian yuridis normatif, yaitu cara atau prosedur yang digunakan untuk memecahkan masalah di dalam penelitian ini dengan melakukan pengumpulan dan pengolahan 
terhadap bahan hukum(Soerjono Soekarto \& Sri Mamudji, 2004). Pendekatan masalah yang dipergunakan dalam penelitian ini adalah pendekatan konseptual (conceptual approach) dan pendekatan peraturan perundang-undangan (statute approach) dan pendekatan kasus (case approach)(Ibrahim, 2005). Pendekatan konseptual (conceptual approach) adalah suatu pendekatan untuk mengkaji dan menganalisis kerangka pikir atau kerangka konseptual maupun landasan teoritis sesuai dengan tujuan penelitian ini.Adapun pendekatan peraturan perundang-undangan (statute approach) yaitu suatu pendekatan yang dilakukan terhadap berbagai aturan hukum yang berkaitan dengan masalah dalam penelitian ini.

\section{PEMBAHASAN}

Hak pendidikan penyandang disabilitas telah diakui dalam Deklarasi Universal Hak Asasi Manusia, hal ini diatur dalam Article 26. T.S.N Sastry (T.S.N Sastry, 2011) menyatakan bahwa pentingnya pendidikan tidak hanya sebagai instrumen untuk mencerdaskan kehidupan manusia, namun juga merupakan instrumen untuk melaksanakan hak asasi manusia yang dijamin baik secara internasional maupun nasional. Untuk itu, T.S.N Sastry mengemukakan beberapa tujuan yang hendak dicapai, yakni:

a. Pendidikan untuk semua orang untuk memperkuat penghormatan dan membantu untuk mempromosikan hak asasi manusia dan kebebasan yang bersifat mendasar.

b. Pengembangan kemampuan personal manusia dan nilai-nilai kemartabatannya dapat dicapai hanya ketika orang-orang sadar akan pentingnya peningkatan hak asasi.

c. Pendidikan membantu untuk memahami, mentoleransi, mempromosikan kesetaraan gender dan persahabatan dengan sesama umat manusia di seluruh dunia.

d. Pendidikan mempromosikan perilaku kepedulian kepada kelompok rentan, seperti pengungsi, kepada orang yang secara mental dan fisik mengalami kecacatan, manusia lanjut usia, anak-anak, jenis kelamin ketiga, orang yang secara sosial, ekonomi dan budaya tidak diuntungkan, dan mempromosikan pengakhiran rasisme, kebahasaan, keagamaan, dan lain sebagainya.

e. Pendidikan mampu mendukung semua orang untuk berperan aktif dan efektif di dalam pengembangan masyarakat dan negara secara ekonomi, politik, sosial, hukum dan budaya.

f. Pendidikan bertujuan untuk mencapai tujuan dari hak asasi manusia dengan cara menanamkan perspektif nilai, moral, dan etika kemanusiaan.

g. Pendidikan bertujuan untuk mencapai tujuan Perserikatan Bangsa-Bangsa dan hukum internasional untuk menciptakan perdamaian dan keamanan dunia.

Senada dengan article 26 The Universal Declaration of Human Rights s, International Covenant on Economic, Social, and Cultural Rights (1966) yang telah diratifikasi dengan UndangUndang Nomor 11 Tahun 2005 juga mengakui bahwa pendidikan merupakan hak asasi manusia bagi setiap orang. Hak pendidikan diatur dalam article 13. Dalam article 13 dapat diketahui bahwa peserta konvensi sepakat dalam beberapa hal yakni :

(1) mengakui hak setiap orang untuk memperoleh pendidikan,

(2) pendidikan harus diarahkan meningkatkan kemampuan manusia dan nilai-nilai kemartabatan yang dimilikinya dan memperkuat hak asasi manusia dan kebebasan, dan

(3) pendidikan harus memungkinkan semua orang untuk ikut berpartisipasi secara efektif dalam masyarakat yang merdeka, mempromosikan kesepahaman, toleransi dan pertemanan antar seluruh negara dan antar seluruh ras, etnik atau kelompok keagamaan, dan lebih lanjut sebagai kegiatan Perserikatan Bangsa-Bangsa untuk menjaga perdamaian.

Dengan kesepakatan di atas, maka dalam rangka untuk memenuhi hak pendidikan bagi setiap orang, peserta konvensi mengakui bahwa (1) pendidikan dasar bersifat wajib dan gratis bagi semua orang, (2) pendidikan tiingkat kedua dalam bentuk yang berbeda termasuk pendidikan teknis dan pendidikan vokasi kedua wajib dibuat secara umum dan dapat diakses oleh semua orang dengan cara yang tepat, (3) pendidikan tinggi harus dapat diakses oleh semua orang secara setara dengan 
dasar kemampuan melalui cara-cara yang tepat, (4) pendidikan dasar harus diintensifkan kepada orang yang tidak menerima atau lulus pendidikan dasar, dan (5) sistem pendidikan dalam seluruh tingkatan harus ditingkatkan dan kemampuan staf pengajar harus ditingkatkan secara berkelanjutan.

Selain kedua instrumen hukum internasional di atas, hak pendidikan juga diatur dalam beberapa konvensi khusus seperti Convention on the Rights of Child (1989) dan Convention on the Elimination of All Forms of Discrimination Againts Women (1979). Berdasarkan article 28 yang menentukan bahwa "States Parties recognize the right of the child to education". Dalam rangka pemenuhan hak pendidikan terhadap anak, maka peserta konvensi harus (1) mejadikan pendidikan dasar wajib dan gratis kepada semua orang, (2) mengembangkan berbagai jenis pendidikan tingkat kedua termasukan pendidikan umum dan vokasi yang terakses oleh setiap anak dan mengambil langkan yang tepat seperti pendidikan gratis dan menyediakan bantuan keuangan dalam kasus-kasus yang membutuhkan, (3) menjadikan pendidikan tinggi yang dapat diakses oleh semua orang dengan dasar kemampuan melalui cara-cara yang tepat, (4) menyediakan informasi dan petunjuk pendidikan dan vokasi yang dapat diakses oleh semua orang, (5) melakukan tindaka-tindakan untuk meningkatkan partisipasi aktif di sekolah dan mengurangi angka drop out. Lebih lanjut dalam article 29 ditentukan bahwa pendidikan bagi anak bertujuan: (1) meningkatan kemampuan anak, bakat dan mental, kemampuan fisik untuk mencapai potensi anak, (2) meningkatkan penghormatan kepada hak asasi manusia dan kebebrasan dan prinsip-prinsip yang ada dalam piagam Perserikatan BangsaBangsa, (3) meningkatkan penghormatan kepada orang tua, identitas budaya, bahasa dan nilai dimana anak itu tinggal, (4) mempersiapkan anak untuk bertanggungjawab dalam masyarakat dengan dasar saling pengertian, perdamaian, toleransi, kesedarajatan seks dan persahabatan diantara semua orang, etnik, kebangsaan, kelompok dan agama, dan (5) meningkatkan penghormatan kepada lingkungan hidup. Adapun dalam article 10 Convention on the Elimination of All Forms of Discrimination Againts Women (1979) ditentukan bahwa perempuan memiliki hak yang sama dengan laki untuk memperoleh pendidikan. Oleh karena itu, negara berkewajiban untuk menjamin prinsip kesetaraan dan non diskriminasi bagi perempuan dan laki-laki untuk memperoleh pendidikan.

Dari konvensi-konvensi di atas, maka secara internasional telah diakui bahwa pendidikan merupakan hak asasi setiap manusia.Bahkan pendidikan dapat dikatakan sebagai basic right disamping hak hidup dan hak kebebasan untuk menunjang pemenuhan hak asasi manusia lainnya.Pendidikan merupakan instrumen untuk mencerdaskan dan memanusiakan manusia itu sendiri. Untuk itu, dalam kedua konvensi tersebut dijelaskan bahwa tujuan pendidikan tidak hanya diarahkan untuk meningkatkan kemampuan personalitas manusia (intelektual dan keterampilan), namun lebih dari itu pendidikan bertujuan sebagai instrumen untuk menyadarkan manusia akan makna eksistensi kemanusiaannya seperti penghormatan hak asasi manusia orang lain, saling mengerti antar sesama, dan non diskriminasi berdasarkan ras, agama dan lain sebagainya. Terkait dengan hal tersebut, Azyumardi Azra menyatakan bahwa pendidikan lebih dari sekedar pengajaran. Pendidikan adalah suatu proses dimana suatu bangsa atau negara membina dan mengembangkan kesadaran diri diantara individu-individu (Azra, 2010). Dengan dasar tersebut, maka pendidikan merupakan kebutuhan dasar (basic need) di samping hak dasar (basic right) bagi setiap individu dan kelompok dalam negara.Pendidikan dibutuhkan untuk membangun dan membangun moral dari warga bangsa itu sendiri.

Di samping telah diatur dalam beberapa konvensi di atas, hak pendidikan bagi setiap orang juga mendapatkan jaminan yang sangat kuat dalam konstitusi Indonesia. Hal tersebut tidak dapat dilepaskan dari adanya ketentuan Pasal 1 ayat (3) UUD NRI Tahun 1945 yang menentukan bahwa Indonesia adalah negara hukum, dengan ciri utamanya adalah perlindungan terhadap hak asasi manusia termasuk hak atas pendidikan. Pasal 31 UUD NRI Tahun 1945 menentukan:

(1) Setiap warga negara berhak mendapat pendidikan.

(2) Setiap warga negara wajib mengikuti pendidikan dasar dan pemerintah wajib membiayainya. 
(3) Pemerintah mengusahakan dan menyelenggarakan satu sistem pendidikan nasional, yang meningkatkan keimanan dan ketakwaan serta akhlak mulia dalam rangka mencerdaskan kehidupan bangsa, yang diatur dengan undang-undang.

(4) Negara memprioritaskan anggaran pendidikan sekurangkurangnya dua puluh persen dari anggaran pendapatan dan belanja negara serta dari aggaran pendapatan dan belanja daerah untuk memenuhi kebutuhan penyelenggaraan pendidikan nasional.

(5) Pemerintah memajukan ilmu pengetahuan dan tekhnologi dengan menjunjung tinggi nilainilai agama dan persatuan bangsa untuk kemajuan peradaban serta kesejahteraan umat manusia.

Dari ketentuan di atas, maka UUD NRI Tahun 1945 menentukan bahwa pendidikan merupakan hak dasar (basic right) bagi setiap warga negara. Bahkan untuk pendidikan dasar merupakan pendidikan wajib bagi warga negara dan negara wajib untuk membiayainya.Selain ketentuan tersebut, ada beberapa pasal dalam UUD NRI Tahun 1945 yang menentukan bahwa pendidikan merupakan hak dasar warga negara. Pasal-pasal tersebut adalah sebagai berikut:

1. Pasal 28 C ayat (1) UUD NRI Tahun 1945 yang menentukan bahwa "Setiap orang berhak mengembangkan diri melalui pemenuhan kebutuhan dasarnya, berhak mendapat pendidikan...".

2. Pasal $28 \mathrm{E}$ ayat (1) UUD NRI Tahun 1945 yang menentukan bahwa "Setiap orang bebas memeluk agama dan beribadat menurut agamanya, memilih pendidikan dan pengajaran,....".

Hak atas pendidikan juga telah diatur dalam Undang-Undang Nomor 39 Tahun 1999 tentang Hak Asasi Manusia. Pasal 12 UU No. 39 Tahun 1999 menentukan "Setiap orang berhak atas perlindungan bagi pengembangan pribadinya, untuk memperoleh pendidikan, mencerdaskan dirinya, dan meningkatkan kualitas hidupnya agar menjadi manusia yang beriman, bertaqwa, bertanggung jawab, berakhlak mulia, bahagia, dan sejahtera sesuai dengan hak asasi manusia". Artinya bahwa pasal tersebut memberikan ketentuan bahwa pendidikan merupakan hak setiap warga negara yang tujuannya adalah untuk menciptakan manusia yang beriman, bertaqwa dan bertanggung jawab sesuai dengan asasi yang dimilikinya. Senada dengan ketentuan di atas, Pasal 5 UU No. 20 Tahun 2003 menentukan bahwa

(1) Setiap warga negara mempunyai hak yang sama untuk memperoleh pendidikan yang bermutu.

(2) Warga negara yang memiliki kelainan fisik, emosional, mental, intelektual, dan/atau sosial berhak memperoleh pendidikan khusus.

(3) Warga negara di daerah terpencil atau terbelakang serta masyarakat adat yang terpencil berhak memperoleh pendidikan layanan khusus.

(4) Warga negara yang memiliki potensi kecerdasan dan bakat istimewa berhak memperoleh pendidikan khusus.

(5) Setiap warga negara berhak mendapat kesempatan meningkatkan pendidikan sepanjang hayat.

Dari ketentuan tersebut, maka pendidikan merupakan hak bagi semua warga negara.Artinya bahwa pendidikan merupakan barang publik (public good) yang harus dapat diakses oleh seluruh warga negara.Akses terhadap pendidikan tersebut sarana bagi seluruh warga negara untuk memperoleh pendidikan yang bermutu untuk meningkat kapasitas dirinya dalam pergaulan berbangsa dan bernegara.Lebih lanjut, Pasal 6 ayat (1) UU No. 20 Tahun 2003 menentukan "Setiap warga negara yang berusia tujuh sampai dengan lima belas tahun wajib mengikuti pendidikan dasar". Senada dengan hal tersebut, Pasal 34 UU No. 20 Tahun 2003 menentukan bahwa:

(1) Setiap warga negara yang berusia 6 tahun dapat mengikuti program wajib belajar

(2) Pemerintah dan pemerintah daerah menjamin terselenggaranya wajib belajar minimal pada jenjang pendidikan dasar tanpa memungut biaya.

(3) Wajib belajar merupakan tanggung jawab negara yang diselenggarakan oleh lembaga pendidikan, Pemerintah, pemerintah daerah dan masyarakat. 
(4) Ketentuan mengenai wajib belajar sebagaimana dimaksud pada ayat (1), ayat (2), dan ayat (3) diatur lebih lanjut dengan peraturan pemerintah.

Di samping dalam peraturan perundang-undangan di atas, ha katas pendidikan juga diatur dalam Undang-Undang Nomor 23 Tahun 2002 tentang Perlindungan Anak.Pasal 9 ayat (1) UU No. 23 Tahun 2002 menentukan "Setiap anak berhak memperoleh pendidikan dan pengajaran dalam rangka pengembangan pribadinya dan tingkat kecerdasannya sesuai dengan minat dan bakatnya".Dari ketentuan di atas, maka setiap anak berhak untuk memperoleh pendidikan untuk pengembangan pribadi sesuai dengan minat dan bakatnya.

SPara penyandang disabilitas memiliki hak asasi yang sama dengan manusia lainnya. Terkait dengan hal tersebut, Declaration on the Rights of Disabled Person (1975) menentukan bahwa "Disabled persons have the same civil and political rights as other human beings". Artinya bahwa penyandang disabilitas juga memiliki hak asasi manusia sebagaimana telah dijamin dalam oleh Universal Declaration of Human Rights (1948), International Covenant on Economic, Social, and Cultural Rights (1966), dan International Covenant on Civil and Political Rights (1966) serta hak asasi manusia lainnya yang diatur dalam beberapa konvensi. Untuk itu, dalam deklarasi tersebut ditentukan bahwa (1) penyandang disabilitas dapat menikmati atau melaksanakan hak-hak yang dijamin dalam deklasi ini tanpa dengan alasan apapun dan tanpa diskriminasi ras, warna kulit, seks, bahasa, politik dan pendapat, kebangsaan dan suku, kenegaraan, kelahiran atau situasi-situasi yang lain.

Dalam deklarasi tersebut telah diatur beberapa hak dari penyandang disabilitas, yakni:

a. hak untuk menghormati martabat kemanusiaan mereka yang sama seperti manusia yang lain apapun asasl, sifat dan derajat disabilitas mereka.

b. Hak untuk memperoleh segala tindakan yang dapat menjadikan mereka mandiri.

c. Hak atas pelayanan kesahatan, psikologis dan fungsional termasuk peralatan peralatan prostetik dan ortetis, hak untuk memperoleh rehabilitasi sosial, pendidikan, pelatihan vokasional dan rehabilitasi, bantuan, konseling dan pelayanan penempatan dan pelayanan lainnya yang memungkinkan mereka untuk meningkatkan kemampuan dan keterampilan secara maksimum dan akan mempercepat integrasi dan reintegrasi kehidupan sosial mereka.

d. Hak ekonomi, keamanan sosial dan tingkat kehidupan yang layak. Mereka berhak untuk untuk memperoleh pekerjaan, terlibat dalam pekerjaan yang memebrikan manfaat, produktif, dan menguntungkan sesuai kemampuan mereka serta berhak untuk bergabung dengan serikat pekerja.

e. Hak untuk memperoleh kebutuhan khusus mereka yang dipertimbangkan dalam setiap tahap perencanaan ekonomi dan sosial.

f. Hak untuk hidup bersama keluarga, berpatisipasi dalam segala kegiatan sosial.

g. Hak untuk memperoleh perlindungan dari segala bentuk eksploitasi, semua aturan atau perlakuan yang bersifat diskriminatif, abuse dan merendahkan hak asasi manusia.

h. Hak untuk memperoleh bantuan hukum untuk memberikan perlindungan diri dan harta mereka. Dalam proses peradilan, pengadilan harus memeprtimbangan kondisi fisik dan mental penyandang disabilitas.

i. Hak untuk memperoleh informasi terhadap hak-hak yang dimiliki.

Untuk memperkuat Declaration on the Rights of Disabled Person (1975) tersebut maka pada tanggal 13 Desember 2006 Perserikatan Bangsa-Bangsa telah menyetujui Convention on the Rights of Person with Disabilities dengan Resolusi 61/106 yang kemudian diratifikasi dengan Undang-Undang Nomor 19 Tahun 2011. Dalam pembukaan konvensi tersebut, negara-negara peserta konvensi mengakui yang pada intinya bahwa penyandnag disabilitas mempunyai hak asasi manusia yang sama dengan manusia yang lain, karenanya diskriminasi terhadap penyandang disabilitas merupakan pelanggaran terhadap martabat dan nilai yang melekat pada setiap orang. Dalam article 1 ditentukan bahwa "Tujuan Konvensi ini adalah untuk memajukan, melindungi dan menjamin penikmatan secara 
penuh dan setara semua hak-hak asasi manusia dan kebebasan fundamental oleh semua penyandang disabilitas, dan untuk meningkatkan penghormatan atas martabat yang melekat pada mereka". Dalam article 4 ditentukan bahwa penyandang disabilitas memiliki hak asasi manusia dan kebebasan tanpa diskriminasi dengan alasan apapun.

Dalam Convention on the Rights of Person with Disabilities telah diatur beberapa hak penyandang disabilitas yakni:

a. Hak untuk memperoleh kesamaan di hadapan hukum dan untuk memperoleh perlindungan hukum yang sama dan efektif (article 5)

b. Perempuan penyandang disabilitas berhak memeproleh jaminan pengembangan, pemajuan, dan pemberdayaan perempuan secara utuh (article 6)

c. Anak penyandang disabilitas berhak hak untuk mengemukakan pandangan mereka secara bebas atas dasar persamaan dengan anak-anak lain (article 7)

d. Hak aksesibilitas terhadap lingkungan fisik, transportasi, informasi, komunikasi, dan akses terhadap fasilitas dan jasa pelayanan lain yang terbuka dan tersedia untuk public baik di pedesaan maupun perkotaan (article 9)

e. Hak untuk hidup (article 10)

f. Hak untuk memperoleh perlindungan dan keselamatan dalam situasi beresiko termasuk konflik bersenjata, gawat darurat kemanusiaan dan bencana alam (article 11)

g. Hak untuk diakui di hadapan hukum atas dasar kesamaan dengan manusia yang lain (article 12)

h. Hak atas akses keadilan yang didasarkan atas dasar kesamaan dengan orang lain (article 13)

i. Hak atas kebebasan dan keamanan (article 14)

j. Hak untuk bebas dari penyiksaan atau perlakuan atau penghukuman yang kejam, tidak manusiawi atau merendahkan martabat manusia (article 15)

k. Hak untuk bebas dari eksploitasi, kekerasan dan perlakuan semena-mena (article 16)

I. Hak untuk mendapatkan penghormatan atas integritas mental dan fisiknya (article 17)

m. Hak atas kebebasan bergerak, kebebasan memilih tempat tinggal dan kewarganegaraan (article 18)

n. Hak untuk hidup secara mandiri dan dilibatkan dalam masyarakat (article 19)

o. Hak mobilitas pribadi (article 20)

p. Hak atas kebebasan berekspresi dan berpendapat serta akses terhadap informasi (article 21)

q. Hak pribadi yang terkait dengan informasi pribadi, kesehatan dan rehabilitas (article 22)

r. Hak penghormatan atas rumah tangga dan keluarga (article 23)

s. Hak atas pendidikan (article 24)

t. Hak atas kesehatan (article 25)

u. Hak atas habilitasi dan rehabilitas (article 26)

v. Hak atas pekerjaan dan lapngan kerja (article 27)

w. Ha katas standar kehidupan dan penghidupan yang layak (article 28)

x. Hak untuk berpartisipasi dalam kehidupan politik dan public (article 29)

y. Hak untuk berpartisipasi dalam kebudayaan, rekreasi, hiburan dan olah raga (article 30)

Dari kedua instrumen hukum internasional di atas, maka salah satu hak asasi penyandang disabilitas adalah hak pendidikan (right to education) yang diatur dalam point ke-6 Declaration on the Rights of Disabled Person (1975) dan article 24 Convention on the Rights of Person with Disabilities. Article 24 Convention on the Rights of Person with Disabilities menentukan:

States Parties recognize the right of persons with disabilities to education. With a view to realizing this right without discrimination and on the basis of equal opportunity, States Parties shall ensure an inclusive education system at all levels and lifelong learning directed to:

a. The full development of human potential and sense of dignity and self-worth, and the strengthening of respect for human rights, fundamental freedoms and human diversity; 
b. The development by persons with disabilities of their personality, talents and creativity, as well as their mental and physical abilities, to their fullest potential;

c. Enabling persons with disabilities to participate effectively in a free society.

Dari article 24 di atas, maka penyandang disabilitas memiliki hak pendidikan yang sama dengan manusia yang lainnya. Bahkan dalam article a quo ditentukan bahwa negara wajib menyediakan sistem pendidikan inklusif bagi penyandang disabilitas di segala jenjang pendidikan dan pendidikan sepanjang hayat. Lebih lanjut hak pendidikan bagi penyandang disabilitas wajib diarahkan pada:

a. Pengembangan seutuhnya potensi diri dan rasa rnartabat dan harga diri, serta penguatan penghormatan atas hak asasi manusia, kebebasan fundamental dan keanekaragaman manusia

b. Pengembangan atas kepribadian, bakat dan kreatifitas, serta kemampuan mental dan fisik dari penyandang disabilitas hingga mencapai potensi sepenuhnya

c. Memungkinkan penyandang disabilitas untuk berpartisipasi secara efektif di dalam masyarakat umum.

Dalam konteks sistem ketatanegaraan Indonesia sebagaimana telah dijelaskan di atas, bahwa hak pendidikan merupakan hak yang dijamin oleh UUD NRI Tahun 1945 dan peraturan pelaksananya.Pasal 31 UUD NRI Tahun 1945 menentukan "Setiap warga negara berhak mendapat pendidikan". Selain itu, Pasal 28C ayat (1) dan Pasal 28E ayat (1) UUD NRI Tahun 1945 juga memberikan jaminan atas setiap warga negara untuk memperoleh pendidikan. Bahkan Pasal 31 ayat (2) UUD NRI Tahun 1945 menentukan "Setiap warga negara wajib mengikuti pendidikan dasar dan pemerintah wajib membiayainya". Senada dengan hal tersebut, Pasal 5 ayat (1) Undang-Undang Nomor 20 Tahun 2003 tentang Sistem Pendidikan Nasional juga menentukan bahwa "Setiap warga negara mempunyai hak yang sama untuk memperoleh pendidikan yang bermutu".

Hak atas pendidikan tersebut tidak hanya menjadi milik warga yang normal secara fisik dan psikis.Namun dengan prinsip equal access, maka warga negara berkebutuhan khusus (difabel) seperti memiliki kelainan fisik, emosional, mental, intelektual, dan/atau sosial juga berhak untuk memperoleh pendidikan yang sesuai dengan kondisinya.Pasal 5 ayat (2) UU No. 20 Tahun 2003 menentukan "Warga negara yang memiliki kelainan fisik, emosional, mental, intelektual, dan/atau sosial berhak memperoleh pendidikan khusus". Senada dengan hal tersebut, Pasal 9 ayat (2) menentukan UU No. 23 Tahun 2002 menentukan "Selain hak anak sebagaimana dimaksud dalam ayat (1), khusus bagi anak yang menyandang cacat juga berhak memperoleh pendidikan luar biasa, sedangkan bagi anak yang memiliki keunggulan juga berhak mendapatkan pendidikan khusus". Lebih lanjut Pasal 51 UU No. 35 Tahun 2014 juga menentukan bahwa "Anak Penyandang Disabilitas diberikan kesempatan dan aksesibilitas untuk memperoleh pendidikan inklusif dan/atau pendidikan khusus".

Di samping beberapa undang-undang di atas, pengaturan mengenai hak pendidikan penyandang disabilitas telah diatur dalam Undang-Undang Nomor 8 Tahun 2016 tentang Penyandang Disabilitas("Undang-Undang Nomor 8 Tahun 2016 tentang Penyandang Disabilitas," n.d.). Pasal 10 UU No. 8 Tahun 2016 menentukan bahwa hak pendidikan untuk Penyandang Disabilitas meliputi hak untuk (1) mendapatkan pendidikan yang bermutu pada satuan pendidikan di semua jenis, jalur, dan jenjang pendidikan secara inklusif dan khusus; (2) mempunyai Kesamaan Kesempatan untuk menjadi pendidik atau tenaga kependidikan pada satuan pendidikan di semua jenis, jalur, dan jenjang pendidikan; (3) mempunyai Kesamaan Kesempatan sebagai penyelenggara pendidikan yang bermutu pada satuan pendidikan di semua jenis, jalur, dan jenjang pendidikan; dan (4) mendapatkan Akomodasi yang Layak sebagai peserta didik. Lebih lanjut Pasal 40 ayat (2) UU No. 8 Tahun 2016 menentukan bahwa hak pendidikan bagi penyandang diasbilitas dilaksanakan dalam sistem pendidikan nasional melalui pendidikan inklusif dan pendidikan khusus.

Dari ketentuan tersebut, maka warga negara penyandang disabilitas berhak untuk memperoleh pendidikan khusus ('Undang-Undang Nomor 20 Tahun 2003 tentang Sistem Pendidikan 
Nasional', no ate). Hal tersebut sesuai dengan prinsip affirmative yang ditentukan dalam Pasal 281 ayat (2) UUD NRI Tahun 1945 yang menentukan "Setiap orang mendapat kemudahan dan perlakuan khusus untuk memperoleh kesempatan dan manfaat yang sama guna mencapai persamaan dan keadilan". Senada dengan hal tersebut, Pasal 5 ayat (3) UU No. 39 Tahun 1999 menentukan bahwa "Setiap orang yang termasuk kelompok masyarakat yang rentan berhak memperoleh perlakuan dan perlindungan lebih berkenaan dengan kekhususannya".

\section{KESIMPULAN}

Kesimpulan dari penelitian ini adalah pendidikan penyandang disabilitas merupakan hak yang telah mendapatkan pengakuan baik dalam aturan internasional maupun nasional. Pengakuan hak pendidikan terdapat pada artikel 26 The Universal Declaration of Human Rights, pada article 13 mengakui pedidikan dasar harus diberika kepada setiap orang dengan Cuma-cuma. International Covenant on Economic, Social, and Cultural Rights (1966) yang telah diratifikasi dengan UndangUndang Nomor 11 Tahun 2005 yang mengakui pendidikan sebagai hak asasi manusia. UUD NRI Tahun 1945 yang menentukan bahwa pendidikan merupakan hak dasar warga negara. Hal ini terdapat pada pasal Pasal 28 C ayat (1) dan Pasal 28 E ayat (1) UUD NRI Tahun 1945. Secara spesifik dalam aturan internasional tentang penyandang disbilitas adalah Convention on the Rights of Person with Disabilities dengan Resolusi 61/106 yang kemudian diratifikasi dengan Undang-Undang Nomor 19 Tahun 2011. Dan hak pendidikan diatur dalam article 24. Hak atas pendidikan juga telah diatur dalam Undang-Undang Nomor 39 Tahun 1999 tentang Hak Asasi Manusia khususnya Pasal 12. Secara spesifiki perlindungan hak penyandang disbilitas termasuk hak pendidikan terdapat dalam UndangUndang Nomor 8 Tahun 2016 Tentang Penyandang Disabilitas. Dengan adanya jaminan pendidikan ini, penyandang disabilitas memiliki jalan yang luas dalam meningkatkan kemampuan diri untuk beradaptasi terhadap teknologi dan untuk mendapatkan standart kehidupan yang lebih baik.

\section{DAFTAR PUSTAKA}

Azra, A. (2010). Paradigma Membangun Karakter Bangsa Melalui Pendidikan. Jakarta: Kompas. Ibrahim, J. (2005). Teori, Metode dan Penelitian Hukum Normatif. Malang: Bayumedia Publishing. Soerjono Soekarto \& Sri Mamudji. (2004). Penelitian Hukum Normatif : Suatu Tinjauan Singkat, Cetakan Kedelapan. Jakarta: RajaGrafindo Persada.

T.S.N Sastry. (2011). Introduction of Human Rights and Duties. Ganeshkhind: University of Pune Press.

Undang-Undang Nomor 20 Tahun 2003 tentang Sistem Pendidikan Nasional. (n.d.). Undang-Undang Nomor 8 Tahun 2016 tentang Penyandang Disabilitas. (n.d.). 